6. Khell L., Zyhler D. (2003) Teoryy lychnosty. Z-e mezhdunar. yzd. [Personality theories]. Sankt-Peterburh: Pyter, 2003.608 s. [in Russia].

7. Shcherban P. M. (2000) Natsionalne vykhovannia v simi. [National upbringing in the family]. Kyiv: Boryviter, $2000.260 \mathrm{~s}$. [in Ukrainian].

\title{
Rudiuk T. V. Psychology of love and the study of family tokens (communicative-activity approach)
}

The article is devoted to topical issues of psychology of love in terms of the proposed research and the functioning of modern Ukrainian schools. The specifics of male and female love; phases of its development and features of interpersonal communication are considered. Emphasis is placed on the need to create the preconditions for conscious personal growth (communicative-activity approach) and to promote the processes of early awareness of the physiological and psychological characteristics of the phenomenon, individual responsibility for starting a family. The effectiveness of these recommendations through the prism of the formation of family lexical competence, educating a conscious attitude to the processes of interaction; research efforts in the field of family communication, training and development of tactics of mutual support is projected.

Among the conditions that ensured the effectiveness of the educational process in the context of mastering these concepts (communicative-activity aspect) the need for multifaceted observations is clarified; systematic self-improvement; promotion of tolerance, processes of psychological self-control and self-analysis. In addition, exercises are offered to critically assess the situation and the idea of the identity being; other types of work, related to linguistic material and relevant creative considerations, practice of the required capabilities to model and predict the common family future. Attention is paid to the understanding of the studied units in line with relevant recommendations (communicative-activity approach) and possible aspects of the innovative vision of educational information.

Conclusions are made about the prospects of further observations in a specified direction, the possibility of intensifying the processes of assimilation of academic material, in particular, conscious use of relevant definitions, establishing causal relationships, discussing conclusions, impressions, etc.

Key words: family vocabulary, communicative-activity approach, family lexical competence, psychology of love, hormones, phases of love, love.

УДК 372.881.1

DOI https://doi.org/10.31392/NPU-nc.series5.2021.79.2.19

Рябокучма Т. О., Горбаченко А. Л.

\section{ЗАСТОСУВАННЯ АВТЕНТИЧНИХ ВІДЕОМАТЕРІАЛІВ У ПРОЦЕСІ ВИВЧЕННЯ ІНОЗЕМНОЇ МОВИ ДЛЯ ЗАБЕЗПЕЧЕННЯ ЕФЕКТИВНОГО ОПАНУВАННЯ НАВИЧОК СЛУХАННЯ ЗДОБУВАЧАМИ ВИЩОЇ ОСВІТИ}

Стаття присвячена застосуванню автентичних відеоматеріалів у процесі вивчення іноземної мови для забезпечення ефективного опанування навичок слухання здобувачами вищої освіти. Метою статті є дослідження особливостей використання автентичних відеоматеріалів та їх спрямованості на покращення навичок слухання у здобувачів вищої освіти (студентів), а також визначення й характеристика основних етапів роботи з відеоматеріалами на занятті з іноземної мови.

У статті визначено головні властивості використання автентичних відеоматеріалів з навчальною метою. Досліджено взаємозв'язок застосування автентичних відеоматеріалів на заняттях з іноземної мови з удосконаленням навичок слухання студентів. Виокремлено та проаналізовано етапи роботи з автентичними відеоматеріалами.

3'ясовано, що є чотири основні типи відеоматеріалів, що можуть бути використані у процесі опанування іноземної мови, а саме спеціально розроблені навчальні матеріали, які входять у комплект сучасних навчально-методичних комплексів; художні фільми, телепередачі та подібні матеріали; ефірні програми, тобто ті, щяо записуються безпосередньо з ефіру; відео, зняті викладачем зі студентами.

У науковій праці представлено та охарактеризовано критерії відбору автентичних відеоматеріалів для заняття з іноземної мови, проаналізовано переваги їхнього застосування для ефективного опанування навичок слухання здобувачами вищої освіти, а також приділено увагу труднощзам, які можуть виникнути під час роботи з відеоматеріалами на занятті з іноземної мови.

Доведено, щуо використання автентичних відеоматеріалів є досить ефективним способом покращення навичок слухання здобувачів вищої освіти. Такі матеріали можуть використовуватися для студентів будь-якої спеціальності та будь-якого рівня володіння іноземною мовою. Виокремлено три етапи роботи з автентичним відеоматеріалом, а саме переддемонстрачійний, спрямований на зняття мовних і лінгвокраїнознавчих труднощів; демонстраційний, спрямований на розвиток навичок сприйняття інформацї̈; післядемонстраційний, спрямований на розуміння змісту відеоматеріалу і розвиток мовних умінь та навичок усного мовлення.

Ключові слова: автентичні відеоматеріали, здобувачі вищої освіти, іноземна мова, слухання, навчальний процес, переддемонстраційний етап, демонстраційний етап, післядемонстраційний етап.

Стрімкий розвиток кіноіндустрії у сучасному світі пропонує велике розмаїття матеріалу для тих, хто опановує іноземну мову. Сьогодні усе частіше кінофільми, мультфільми, телепрограми, рекламні ролики пропонуються як засоби розвитку та вдосконалення мовленнєвих навичок здобувачів вищої 
освіти під час вивчення ними іноземної мови. 3 їхньою допомогою можливо значно покращити базові уміння, які повинен опанувати кожен, хто має на меті успішне вивчення іноземної мови. 3 огляду на те, що перегляд кінофільмів та відеоматеріалів іншого формату є одним з найпопулярніших занять серед молоді, зростає актуальність дослідження використання автентичних відеоматеріалів на заняттях з іноземної мови для забезпечення опанування здобувачами вищої освіти усіх видів мовленнєвих навичок, зокрема слухання.

Мета статті полягає у вивченні особливостей використання автентичних відеоматеріалів, спрямованого на покращення навичок слухання у здобувачів вищої освіти (студентів), а також визначенні та характеризуванні основних етапів роботи з відеоматеріалами на занятті з іноземної мови.

Досягнення мети наукової праці передбачає вирішення таких завдань:

- визначити головні властивості використання автентичних відеоматеріалів з навчальною метою;

- дослідити взаємозв'язок застосування автентичних відеоматеріалів на заняттях з іноземної мови з удосконаленням навичок слухання студентів;

- визначити етапи роботи з автентичними відеоматеріалами та проаналізувати кожен 3 них.

Для досягнення поставленої мети у ході дослідження було використано комплекс методів наукового пізнання, таких як аналіз, синтез, конкретизація, узагальнення, що стали у нагоді під час вивчення наукової літератури з теми та систематизації теоретичного матеріалу дослідження, метод спостереження та описовий метод, що дали змогу проаналізувати етапи роботи з відеоматеріалами на занятті, охарактеризувати переваги їхнього використання на заняттях з іноземної мови для удосконалення навичок слухання та виявити труднощі, які можуть виникати під час роботи з автентичними відеоматеріалами.

Відеоматеріали є одним зі способів представлення та опанування навчального матеріалу як в аудиторії, так і поза нею. Автентичне відео завжди наближає студентів до природних умов використання мови, що вивчається. Використання відеоматеріалів на заняттях $з$ іноземної мови має бути підпорядковане певним навчальним цілям та організовуватися відповідно до них. Т. В. Рябуха та Н. О. Гостищева [6] пояснюють доцільність використання відеоматеріалів у процесі вивчення іноземної мови такими характеристиками:

- доступність відеоматеріалів, адже вони можуть бути записані на різних носіях;

- наявність досвіду роботи з відеопродукцією і відеотехнікою (як у викладача, так і у студентів);

- можливість надати діяльності викладача більш творчого забарвлення.

Дослідниці також виокремлюють такі чотири основні типи відеоматеріалів, що можуть бути використані у процесі опанування іноземної мови:

- спеціально розроблені навчальні матеріали, які входять у комплект сучасних навчально-методичних комплексів (головною їхньою перевагою є зрозумілість для здобувачів вищої освіти, адже вони спеціально розробляються для студентів з урахуванням їхнього рівня володіння іноземною мовою);

- художні фільми, телепередачі тощо;

- ефірні програми, тобто ті, що записуються безпосередньо з ефіру (новини, науково-пізнавальні програми тощо) (перевагою таких матеріалів $\epsilon$ те, що викладач може записувати будь-що, враховуючи уподобання та рівень студентів);

- відео, зняті викладачем зі студентами (зйомка відео з навчальною метою може значно урізноманітнити процес навчання, зробити його значно більш захопливим для студентів, отже, допомогти їм покращити власні результати в опануванні мови) [6].

Безсумнівно, використання автентичних відеоматеріалів на заняттях з іноземної мови допомагає опановувати студентам новий лексичний матеріал, навчатися ефективніше сприймати носіїв мови на слух, знайомитися з життям і культурними цінностями народу, мова якого вивчається. Проте для того щоб досягнути бажаного ефекту, викладачеві необхідно дуже уважно та ретельно підбирати відео для занять.

Перш за все необхідно звернути увагу на якість матеріалу. Особливістю будь-якого відеоматеріалу є його аудіовізуальна структура, тобто наявність двох складових частин, а саме зображення та звуку. Під час вибору матеріалу для заняття варто звертати увагу на кожен із них. I звук, і зображення мають бути чіткими, без жодних технічних дефектів, адже вони можуть мати негативний вплив на процес опанування конкретного навчального матеріалу на занятті і навіть порушити цілісне сприйняття матеріалу студентами, отже, робота з таким матеріалом стане менш якісною.

Не менш важливим за технічний критерій є мовний. Насамперед варто вибирати матеріал, що відповідає рівню підготовки здобувачів вищої освіти. Занадто складний матеріал з великою кількістю незнайомих лексичних одиниць та граматичних конструкцій, незрозумілою для студентів вимовою (наприклад, якщо мовець має специфічний акцент чи у його мовленні присутні регіональні діалекти) призведе до нездатності студентів його сприйняти і працювати з ним на занятті. 3 іншого боку, не варто також використовувати відеоматеріали зі спрощеним лексичним чи граматичним наповненням. Занадто простий матеріал може спричинити втрату інтересу студентів до роботи з ним. Звісно, під час використання спеціально розроблених матеріалів такі труднощі навряд чи можуть виникнути, адже у такому разі всі матеріали адаптуються під рівень студентів та їхню фахову спрямованість.

Загальновідомо, що однією з найактуальніших проблем методики викладання іноземних мов є досягнення комунікативної компетентності тими, хто вивчає мову. Однак опанувати комунікативну компетент- 
ність поза межами країни, мова якої вивчається, досить непросто. У такому разі автентичні відеоматеріали допомагають створити реальні та уявні ситуації спілкування на занятті [5].

Навички слухання (аудіювання) є однією з важливих складових частин комунікативної компетентності мовця або того, хто вивчає мову. Без них неможливо зробити процес спілкування повноцінним та ефективним, отже, під час вивчення іноземної мови у закладі вищої освіти необхідно приділяти особливу увагу розвитку навичок слухання.

Хоча навички читання, мовлення та письма мають велике значення для розвитку мовної компетентності, слухання насамперед пробуджує сприйняття мови такою, якою вона є. Вимова, ритм, інтонація, наголос - усе це може бути перейняте у мовлення того, хто вивчає мову, лише завдяки слуханню. Якщо людина здатна сприймати на слух мову, яку вона вивчає, їй стає легше вдосконалити інші навички та досягти успіху у вивченні цієї мови, адже без належного розуміння іноземного матеріалу той, хто вивчає мову, не зможе досягти жодного успіху. Зрозуміло, що без уміння слухати неможливо навчитися правильно висловлюватися іноземною мовою [8, с. 60].

Використання автентичних відеоматеріалів є досить ефективним способом покращення навичок слухання здобувачів вищої освіти, а такі матеріали можуть використовуватися для студентів будь-якої спеціальності та будь-якого рівня володіння іноземною мовою.

Головною перевагою застосування відеоматеріалу для розвитку навичок слухання є візуальний супровід. Відеоряд у будь-якому разі допомагає сприймати інформацію на слух. Навіть нерозуміння деяких слів чи висловів мовця може компенсуватися візуальною інформацією, тобто тим, що відбувається на екрані. Зображення завжди сприяє кращому розумінню почутого і його аналізу, тому особливо важливо застосовувати автентичні матеріали під час вивчення іноземної мови для студентів немовних спеціальностей і тих, хто лише став на шлях опанування мови іншого народу.

Ще однією позитивною рисою використання відеоматеріалів для поліпшення навичок слухання здобувачів вищої освіти є можливість вмикати субтитри. Особливо це стає у нагоді під час перегляду відео зі спеціальної тематики або тоді, коли мовець говорить занадто швидко чи має специфічний акцент. Звісно, не варто зловживати використанням субтитрів у навчанні мови шляхом перегляду відеоматеріалів, особливо коли йдеться про орієнтацію на навички слухання, адже субтитри дещо спрощують завдання студента, оскільки він може прочитати почуте на екрані і докладати менше зусиль, аби саме почути те, про що говориться. Саме тому вважаємо доцільним використання субтитрів під час перегляду автентичних відеоматеріалів лише у вищезазначених випадках.

Звісно, не варто забувати про інтерес здобувача вищої освіти до діяльності на занятті. Спираючись на власні професійні спостереження, можемо стверджувати, що перегляд відеоматеріалу завжди викликає більший інтерес у студентів і краще стимулює їх до активної діяльності на занятті, ніж прослуховування аудіозапису.

Однак, незважаючи на цінність відеоматеріалів як засобу опанування мови іншого народу та вдосконалення комунікативної компетенції того, хто вивчає мову, іноді робота з ними на занятті зводиться лише до перегляду фільму/відео/програми й можливого його подальшого обговорення. Такий підхід, на нашу думку, перериває процес освоєння матеріалу, поглиблення знань та вдосконалення навичок здобувачів вищої освіти. Однак у сучасних працях, які досліджують використання автентичних відеоматеріалів у навчальному процесі у вищій школі $[1 ; 2 ; 3 ; 4 ; 7]$, простежуємо поділ роботи з автентичним відеоматеріалом на такі три етапи, як переддемонстраційний, демонстраційний, післядемонстраційний. Переддемонстраційний етап спрямований на зняття мовних і лінгвокраїнознавчих труднощів; демонстраційний - на розвиток навичок сприйняття інформації; післядемонстраційний - на розуміння змісту відеоматеріалу та розвиток мовних умінь і навичок усного мовлення [2].

Метою першого етапу є підготовка здобувачів вищої освіти до перегляду відеоматеріалу. Для початку можна запропонувати студентам припустити, про що буде відео, виходячи з його назви, обговорити те, які нові знання вони можуть отримати від перегляду такого матеріалу. На цьому етапі дуже важливо ознайомити студентів з новою лексикою, якщо така присутня у відео, аби уникнути непорозумінь під час його перегляду. Можна навіть виконати певні вправи з новими лексичними одиницями, аби здобувачі вищої освіти краще їх засвоїли і запам’ ятали.

Головною частиною другого (демонстраційного) етапу є перегляд відеоматеріалу. Під час його перебігу обов'язково має враховуватися тривалість відео: якщо воно занадто довге, то можна розбити його на частини і працювати 3 кожною окремо, аби не перевантажувати студентів. Також для початку можна переглянути матеріал повністю, аби студенти отримали загальне уявлення про те, з чим вони працюватимуть. Далі буде доцільно переглянути відео ще раз, але вже із зупинками, під час кожної з яких можна або обговорити почуте (переглянуте), або запропонувати студентам виконати певні усні чи письмові завдання на основі почутого. До таких завдань відносимо повторення за мовцем, надання коментарів щодо почутого, висловлення власної думки.

Післядемонстраційний етап спрямований на забезпечення інтересу студентів щодо подальшої роботи з теми. Викладач може запропонувати студентам попрацювати у парах і скласти діалоги, де вони додатково зможуть попрактикувати навички слухання, адже перебуватимуть у реальній ситуації спілкування. 
Незважаючи на всю користь використання автентичних відеоматеріалів на заняттях з іноземної мови для удосконалення навичок слухання, Т. В. Рябуха та Н. О Гостищева [6] наголошують на труднощах, що можуть виникати під час роботи з відеоматеріалами. До них перш за все належить страх студентів не зрозуміти мовця на екрані. Щоб уникнути такої ситуації, викладачеві слід ретельно підбирати та готувати матеріал до заняття, а також не нехтувати переддемонстраційними завданнями. До того ж ефективним засобом запобігання страху та хвилювання студентів перед виконанням таких завдань може стати створення позитивної і дружньої атмосфери на занятті. Це створить сприятливий психологічний клімат і, відповідно, оптимізує навчальну діяльність здобувачів вищої світи та налаштує їх на роботу з відеоматеріалом. Існує також можливість того, що хтось зі студентів уже знайомий із запропонованим матеріалом. У такому разі у нагоді стануть цікаві післядемонстраційні завдання, які допоможуть утримати інтерес студента до роботи із запропонованим відеоматеріалом.

Висновки. Отже, використання автентичних відеоматеріалів на заняттях з іноземної мови у вищій школі значно сприяє поліпшенню та вдосконаленню навичок слухання здобувачів вищої освіти. Автентичні відеоматеріали допомагають урізноманітнити процес вивчення іноземної мови, зробити його цікавішим та більш творчим, наблизити тих, хто вивчає мову, до природних умов іiі використання та створити реальні ситуації спілкування на занятті.

Під час підготовки заняття з використанням відеоматеріалів викладачеві необхідно звертати увагу на якість матеріалу з точки зору технічних та мовних характеристик. Відео має бути цікавим для студентів 3 точки зору сюжету, а також пропонувати багатий лексичний матеріал. Поетапне виконання переддемонстраційних, демонстраційних і післядемонстраційних завдань дасть змогу здобувачам вищої освіти уникнути можливих труднощів та налаштує студентів на ефективне опрацювання матеріалу, отже, підвищить їхню мотивацію до навчання та допоможе досягти успіху в опануванні іноземної мови.

\section{Використана література:}

1. Журавель Т. В. Використання автентичних відеоматеріалів на заняттях з іноземної мови для студентів-юристів. Подолання мовних та комунікативних бар'єрів: освіта, наука, культура : збірник наукових праць. Київ : Аграр Медіа Груп, 2016. C. 106-110.

2. Конопляник Л. М., Коваленко О. О. Використання автентичних відеоматеріалів для формування іншомовної професійної комунікативної компетентності майбутніх інженерів. Вісник Національного авіаційного університету. Серія: Педагогіка, Психологія. 2016. № 9. С. 90-96.

3. Мунтян А. О. Використання автентичних письмових та аудіо/відеоматеріалів при навчанні іноземної мови. Англістика та американістика. 2015. Вип. 12. С. 88-94.

4. Отрощенко Л. С. Використання відеоматеріалів на уроках німецької мови у немовних ВНЗ. Вища освіта України у контексті інтеграиії до Європейського освітнього простору. 2012. T. IV (37). C. 355-360.

5. Пшеняннікова Н. О. Використання відеофільмів на уроках англійської мови. Науковий вісник Донбасу. 2012. № 1. URL: http://nbuv.gov.ua/UJRN/nvd 2012_1_13 (дата звернення: 07.02.2021).

6. Рябуха Т. В., Гостищева Н. О. Використання відеоматеріалів у навчанні іноземної мови. URL: http://www.rusnauka.com/9 NND 2014/Philologia/1 163379.doc.htm (дата звернення: 07.02.2021).

7. Штельмах О. В. Відеоурок як метод розвитку комунікативної компетенції у студентів технічного вузу на заняттях іноземної мови. Проблеми підготовки сучасного вчителя. 2013. № 8 (2). С. 104-109.

8. Renukadevi D. The Role of Listening in Language Acquisition; the Challenges \& Strategies in Teaching Listening. International Journal of Education and Information Studies. 2014. Vol. 4. № 1. P. 59-63.

\section{References:}

1. Zhuravel T. V. (2016) Vykorystannia avtentychnykh videomaterialiv na zaniattiakh z inozemnoi movy dlia studentiv-yurystiv [The use of authentic video materials during foreign language classes for law students]. Podolannia movnykh ta komunikatyvnykh barieriv: osvita, nauka, kultura : zb. nauk. prats. Kyiv : Ahrar Media Hrup. S. 106-110. [in Ukrainian]

2. Konoplianyk L. M., Kovalenko O. O. (2016) Vykorystannia avtentychnykh videomaterialiv dlia formuvannia inshomovnoi profesiinoi komunikatyvnoi kompetentnosti maibutnikh inzheneriv [The use of authentic video materials for the formation of foreign language professional communicative competence of future engineers]. Visnyk Natsionalnoho aviatsiinoho universytetu. Ser. Pedahohika, Psykholohiia. № 9. S. 90-96. [in Ukrainian]

3. Muntian A. O. (2015) Vykorystannia avtentychnykh pysmovykh ta audio/videomaterialiv pry navchanni inozemnoi movy [The use of authentic written and audio/video materials in foreign language teaching]. Anhlistyka ta amerykanistyka. Vyp. 12. S. 88-94. [in Ukrainian]

4. Otroshchenko L. S. (2012) Vykorystannia videomaterialiv na urokakh nimetskoi movy u nemovnykh VNZ [The use of video materials in German classes in non-language higher educational establishments]. Vyshcha osvita Ukrainy u konteksti intehratsii do Yevropeiskoho osvitnoho prostoru. T. IV (37). S. 355-360. [in Ukrainian]

5. Psheniannikova N. O. (2012) Vykorystannia videofilmiv na urokakh anhliiskoi movy [The use of videos in English lessons]. Naukovyi visnyk Donbasu. № 1. URL: http://nbuv.gov.ua/UJRN/nvd 2012113 (data zvernennia: 07.02.2021). [in Ukrainian]

6. Riabukha T. V., Hostyshcheva N. O. Vykorystannia videomaterialiv u navchanni inozemnoi movy [The use of videomaterials in foreign language teaching]. URL: http://www.rusnauka.com/9_NND_2014/Philologia/1_163379.doc.htm (data zvernennia: 07.02.2021). [in Ukrainian]

7. Shtelmakh O. V. (2013) Videourok yak metod rozvytku komunikatyvnoi kompetentsii u studentiv tekhnichnoho vuzu na zaniattiakh inozemnoi movy [Video lesson as a method of developing communicative competence of students of technical universities in foreign language classes]. Problemy pidhotovky suchasnoho vchytelia. № 8 (2). S. 104-109. [in Ukrainian]

8. Renukadevi D. (2014) The Role of Listening in Language Acquisition; the Challenges \& Strategies in Teaching Listening. International Journal of Education and Information Studies. Vol. 4. № 1. P. 59-63. 
Riabokuchma T. O., Horbachenko A. L. The use of authentic video materials in the process of foreign language learning to ensure effective mastering of listening skills by students of higher educational establishments

The article is devoted to the use of authentic video materials in the process of learning a foreign language to ensure effective mastering of listening skills by students of higher educational establishments. The purpose of the article is to explore the features of the use of authentic video materials, and their focus on improving listening skills of students of higher educational establishments, as well as to identify and describe the main stages of work with video materials during a foreign language class.

The article identifies the main characteristics of using authentic video materials for educational purposes. The relationship between the use of authentic video materials in foreign language classes and the improvement of students'; listening skills has been studied. The stages of work with authentic video materials are singled out and analyzed.

It was found that there are four main types of video materials that can be used in the process of mastering a foreign language: specially designed educational materials that are part of modern educational and methodological complexes; feature films, TV shows and the like; on-air programs, i.e. those that are recorded directly from the air; videos made by a lecturer with students.

The research paper presents and characterizes the criteria for selecting authentic video materials for a foreign language class, analyzes the advantages of their use for effective mastering of listening skills by students of higher educational establishments, and focuses on the difficulties that may arise when working with authentic video materials during a foreign language class.

It has been proven that the use of authentic video materials is a highly effective way to improve listening skills of students of higher educational establishments. Such materials can be used for students of any specialty and any level of foreign language proficiency. There are 3 stages of work with authentic video materials: pre-viewing stage is aimed at removing language and linguistic difficulties; viewing stage is aimed at developing information perception skills; post-viewing stage is aimed at understanding the content of the video and the development of language and oral skills.

Key words: authentic video materials, students of higher educational establishments, foreign language, listening, educational process, pre-viewing stage, viewing stage, post-viewing stage.

УДК 373.043.2-056.2/.3

DOI https://doi.org/10.31392/NPU-nc.series5.2021.79.2.20

Садова I. I., Калита Н. I.

\title{
ТЕХНОЛОГІЇ ІНДИВІДУАЛІЗАЦЇ̈ ОСВІТНЬОГО ПРОЦЕСУ ТА ДИФЕРЕНЦІЙОВАНОГО ВИКЛАДАННЯ В ІНКЛЮЗИВНІЙ ПРАКТИЦІ
}

\begin{abstract}
Здійснено системний аналіз основних технологій інклюзивного навчання, зокрема: 1) індивідуалізації процесу навчання дітей з особливостями психофізичного розвитку (з порушеннями зору, слуху, мовлення, опорно-рухового апарату, із затримкою психічного розвитку, із синдромом дефіциту уваги та гіперактивністю, з розладами аутистичного спектру тощчо); 2) диференційованого викладання, щчо враховує здібності та інтереси учнів з особливими освітніми потребами, профіль навчання, використовувані форми й методи навчальної діяльності, специфіку інклюзивного освітнього середовища, характер та обсяг навчального матеріалу. Узагальнено тлумачення понять “індивідуалізація", “індивідуальний підхід”, “диференційоване викладання”, враховуючи різноманітні аспекти організації та функціонування інклюзивного освітнього процесу. Наголошено на важливості індивідуалізащії і диференціації навчання в інклюзивній практиці шляхом урізноманітнення форм, методів $і$ засобів викладання. 3'ясовано, щчо реалізація диферениіаиії викладання зумовлена певними чинниками, а саме: 1) різним рівнем знань учнів; 2) різними інтересами і стилями навчання; 3) різним темпом навчання (темпераментом), мотивачією; 4) відмінностями в засвоєнні навчального матеріалу; 5) узгодженням традиційних колективних форм навчання з індивідуальним характером засвоєння навчальної інформації тощзо. Обтрунтовано, щзо, по-перше, сучасні освітяни визнають технології інклюзивного навчання діяльнісним інструментарієм та готові застосувати найновітніший з них; по-друге, поєднання традииійних та інноваиійних технологій навчання зумовлює ефективність інклюзивного освітнього процесу, сприяє розвитку інтересів, нахилів $i$ здібностей дітей з особливими освітніми потребами, мотивує їх до розкриття внутрішнього потенціалу.

Ключові слова: інклюзивна освіта, діти з особливими освітніми потребами, технологї̈ індивідуалізації освітнього процесу, диференщійоване викладання в інклюзивній практиці.
\end{abstract}

Першочерговим і важливим чинником розвитку інклюзивної практики, на думку вітчизняних та зарубіжних дослідників (Т. Бондар, К. Волкова, Т. Дегтяренко, І. Демченко, М. Ейнскоу, І. Малишевська, О. Мартинчук, С. Миронова, 3. Шевців та ін.), є підготовка компетентних педагогів, здатних і готових ефективно працювати 3 дітьми $з$ особливими освітніми потребами (далі - ООП). При цьому в сучасній інклюзивній освіті недостатньо розробленими залишаються питання успішного впровадження технологій інклюзивного навчання учнів з ООП. У контексті інклюзивної освіти педагогічна технологія охоплює всі аспекти й елементи педагогічної системи - від постановки цілей до проєктування всього освітнього процесу та перевірки його результативності. Сучасні вітчизняні дослідники Л. Вавіна, В. Засенко, А. Колупаєва, Т. Сак, Н. Софій, О. Таранченко та ін., розглядаючи педагогічну технологію інклюзивного навчання як процесуальну складову 